\title{
Vegetation Management 1994 Fiscal Year End Report
}

\author{
J. M. Rodriguez
}

Date Published

February 1995

Prepared for the U.S. Department of Energy Assistant Secretary for

Environment, Safety, and Health

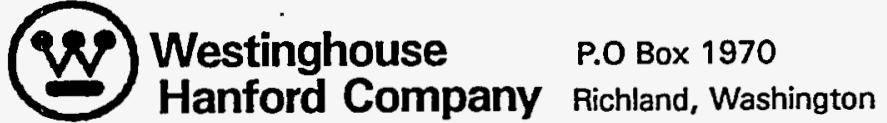

Hanford Operations and Engineering Contractor for the

U.S. Department of Energy under Contract DE-ACO6-87RL10930

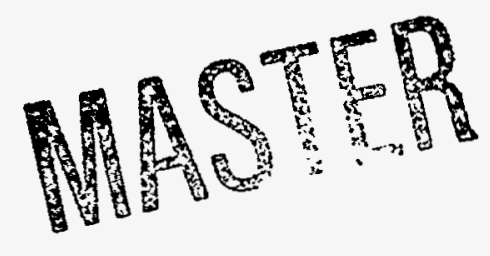

Approved for Public Release 


\section{DISCLAIMER}

This report was prepared as an account of work sponsored by an agency of the United States Government. Neither the United States Government nor any agency thereof, nor any of their employees, make any warranty, express or implied, or assumes any legal liability or responsibility for the accuracy, completeness, or usefulness of any information, apparatus, product, or process disclosed, or represents that its use would not infringe privately owned rights. Reference herein to any specific commercial product, process, or service by trade name, trademark, manufacturer, or otherwise does not necessarily constitute or imply its endorsement, recommendation, or favoring by the United States Government or any. agency thereof. The views and opinions of authors expressed herein do not necessarily state or reflect those of the United States Government or any agency thereof. 


\section{DISCLAIMER}

Portions of this document may be illegible in electronic image products. Images are produced from the best available original document. 


\section{RELEASE AUTHORIZATION}

Document Number: WHC-EP-0849

Document Title: Vegetation Management 1994 Year .End Report

Release Date: $\quad 2 / 8 / 95$

This document was reviewed following the procedures described in WHC-CM-3-4 and is:

APPROVED FOR PUBLIC RELEASE

WHC Information Release Administration Specialist:

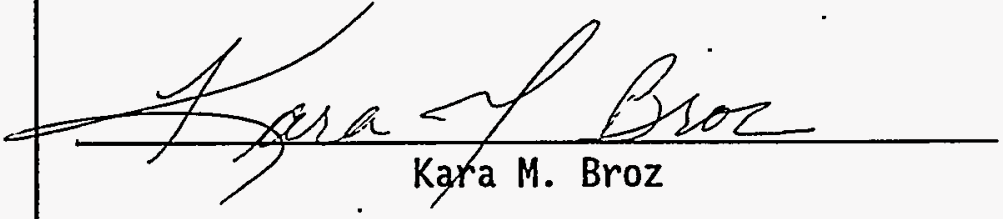

February 8, 1995 


\section{CONTENTS}

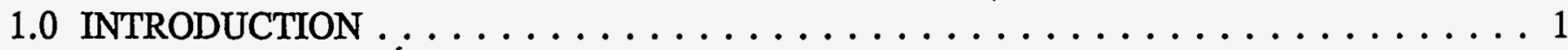

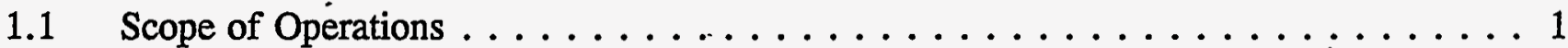

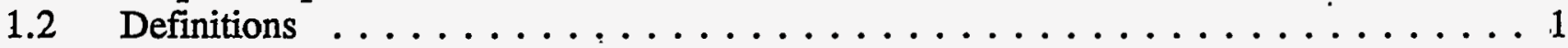

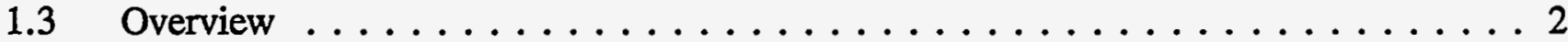

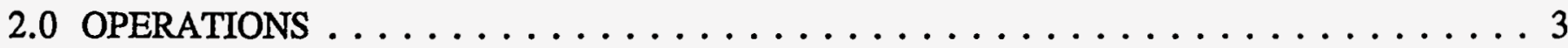

2.1 Fiscal Year 1994 Vegetation Management Strategy . . . . . . . . . . . . . . . . . 3

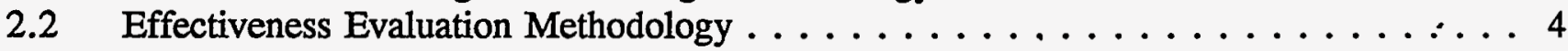

2.3 Findings and Recommendations ..................... 6

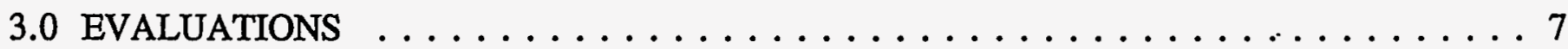

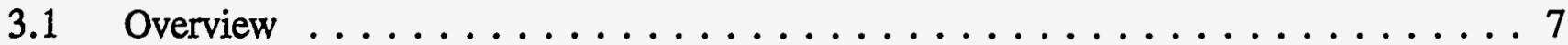

3.2 Vended Ground Herbicide Application Services . . . . . . . . . . . . . 7

3.3 Miscellaneous Sites ............................. 10

3.4 Rights of Way $\ldots \ldots \ldots \ldots \ldots \ldots \ldots \ldots$

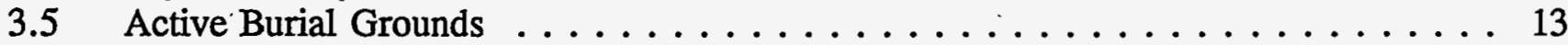

3.6 Waste Tank Operations . . . . . . . . . . . . . . . . . . . . . . 13

3.7 Radiation Area Remedial Action ....................... 15

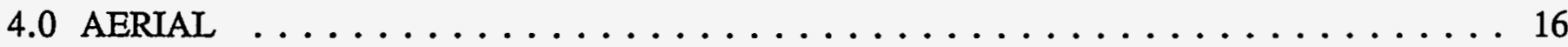

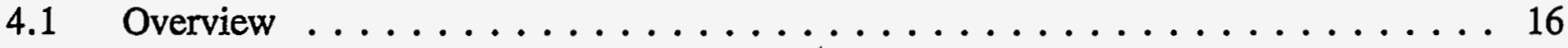

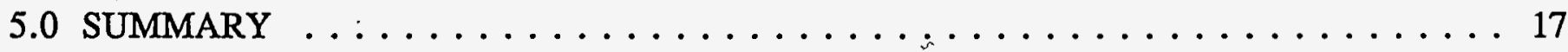

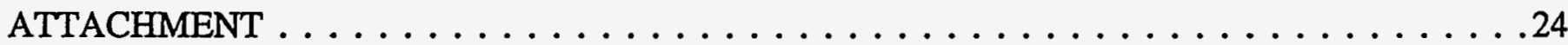




\section{LIST OF FIGURES}

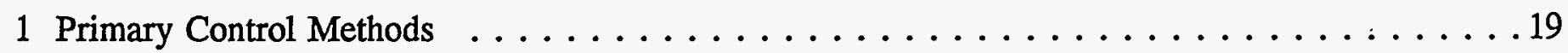

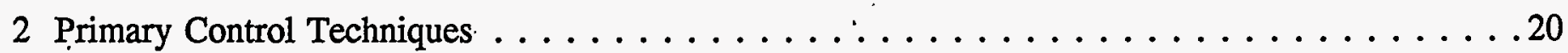

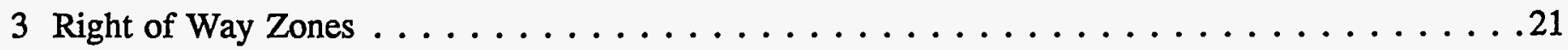

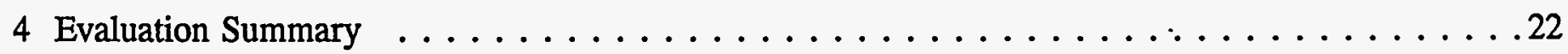

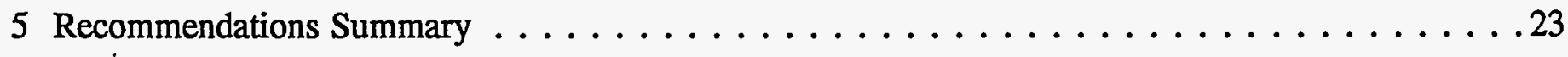




\subsection{INTRODUCTION}

This year-end report evaluates vegetation management operations conducted during fiscal year (FY) 1994 and proposes control methods to be used in FY 1995 and following years. The 1995 control methods proposed are based on an evaluation of past and current ALARA principles, employee safety, environmental impacts, applicable regulations, site esthetics, and other site-specific factors.

\subsection{Scope of Operations}

Vegetation management operations at Hanford span the entire $560 \mathrm{mi}^{2}$, with more than 6,000 acres under active management in 1,000+ work sites. The Vegetation Management Operations (VMO) group performs applications (including rail line) and coordinates and supervises applications by offsite vendors.

Various control methods and materials are used to address the vast diversity of customer requirements. An approximate distribution of the primary control methods employed (by acreage) is illustrated in Figure 1. Within each primary category, a number of tactics were used. Figure 2 depicts the principal chemical and mechanical control techniques used. The cultural control method primarily consisted of drill seeding, employed in connection with interim stabilization projects.

\subsection{Definitions}

Vegetation Management - The environmentally sound manipulation of vegetation to achieve a desired objective.

Control - Preventing the proliferation of target vegetation through deterrence of further seed production and distribution.

Chemical Control - The use of herbicides to control target vegetation.

- Mechanical Control - The use of people or equipment to mow, pull, or otherwise control target vegetation.

Cultural Control - The alteration of environmental factors, (i.e., moisture, soil fertility, competitive species) to support vegetation management efforts. 
Biological Control - The introduction of biological agents/pests to damage and control target vegetation.

Integrated Vegetation Management - The incorporation of any and all appropriate control methods in accomplishing a vegetation management goal.

Application Window - The time during which it is most appropriate to apply a given herbicide to achieve maximum efficiency. ("Windows" can also apply to other control methods.)

Residual Herbicide - An herbicide that persists in soil for more that 21 days in concentrations sufficient to continue to effectively control target vegetation.

Selective Herbicide - An herbicide that selectively controls a target species or class of vegetation, while leaving desirable vegetation undamaged.

\subsection{Overview}

The VMO program has undergone significant changes and reorganizations since 1992. These changes were part of a strategy to consolidate activities into one organization. Improvements such as the following have allowed VMO to better serve each customer.

- $\quad$ Redistribution of workload for herbicide applications

- Two 3-yr herbicide application service contracts awarded in FY 1993

- Continuous evaluation of vegetation management operations

- Consolidation into the Integrated Pest Management organization

- Acquisition of new application equipment

- Continued use of offsite vendors

- Streamlining of Vegetation Management Operations group

- Herbicide formulation changes.

The VMO FY 1994 strategy is detailed in Section 2.0 below, followed by a detailed evaluation of actual performance in Section 3.0. Section 4.0 provides an independent discussion of the Aerial Herbicide Application Program, which overlaps several jurisdictions and locations. 


\subsection{OPERATIONS}

\subsection{Fiscal Year 1994 Vegetation Management Strategy}

Vegetation management operations in FY 1994 were structured around control needs and proper application windows. Highest priority was given to "mission related" requirements (i.e., controlling the spread of radionuclides by vegetation), followed by "administrative" requirements (e.g., safety/security, municipal/regulatory, esthetics). Actual control measures were then scheduled accordingly, in terms of both timing and importance.

The vegetation management strategy addressed residual application sites first, where the goal is to establish or maintain bare ground. Such sites include the following:

- Cobbled burial grounds

- Tank farms

- $\quad$ Security fence lines

- $\quad$ Road and rail rights-of-way

- $\quad$ Graveled parking lots.

Residual herbicides require incorporation into the soil. Therefore, these sites need to be treated during a window when 1.5 to 2 inches of precipitation can be expected soon after the application.

Sites with mixed desirable and undesirable vegetation were addressed next, and were targeted for selective treatment. The goal is to control undesirable vegetation and encourage perennial grass stands. These sites included the following:

- $\quad$ Active burial grounds

- Decommissioned, stabilized sites

- $\quad$ Active cribs, ponds, and ditches.

Selective herbicides decompose quickly: A site targeted for selective weed control may require multiple re-treatments during appropriate application windows. To maintain year-round control of undesirable vegetation, four such treatments were scheduled during FY 1994. 
Non-selective, non-residual herbicides are used as necessary for touch-up/breakthrough treatments.

Because the FY 1994 workscope was too extensive to be supported entirely by the VMO staff, offsite vendors were again retained to assist in the timely application of herbicides. An aerial and a ground vendor were used.

A ground application vendor performed 8 types of applications including liquid, residual-nonselective, granular, residual-nonselective, liquid, residual-selective, granular, residual-selective, non-crop selective (liquid), non-crop selective (granular), aquatic weed control, turf, and spot treatment. Some examples of applications include granular residual herbicide applications (300 Area, ISV site, Patrol Training Academy, and electrical substations), liquid residual herbicide applications $(400,3000,100 \mathrm{~N}, \mathrm{LERF}$, and 100 Areas Radiation Area Remedial Action sites) and lawn care services (100N, 200, 300, 400, 700, 1100, and Fire Stations). The aerial herbicide vendor provided selective herbicide applications. This program is discussed in detail in Section 4.0.

Part of the 1994 strategy, consolidating Vegetation Management into one organization, improved effectiveness and decreased cost. The service request procedure/feedback process was improved to better serve customers. This improvement, allowed VMO to better prioritize and coordinate work site-wide, which resulted in increased productivity, lower costs, and improved application effectiveness. All scheduled work was completed on at a decreased cost.

\subsection{Effectiveness Evaluation Methodology}

To objectively evaluate the effectiveness of vegetation management conducted in FY 1994, VMO continued to use the Effectiveness Evaluation developed in FY 1992. The rating system is described below and is used as part of the site evaluations discussed in Section 3.0 of this report. Note, however, that the evaluation of herbicide application effectiveness is only one portion of the overall evaluation.

At the end of a treatment cycle, each site is inspected and evaluated using three primary criteria:

1. The amount of target vegetation at the site (percent ground cover).

2. The distribution pattern of target vegetation at the site.

3. The impact of the herbicide application on normal development of target vegetation (plant vigor). 
The table below provides the rating scale for the criteria; the rating is used for every site treated. The ratings range from 1 to 5,1 being the most desirable and 5 being failure to control target vegetation. A rating of 2 is the minimum rating for an application to be considered effective.

\begin{tabular}{|c|c|c|c|}
\hline \multicolumn{4}{|c|}{ Vegetation Management Effectiveness } \\
\hline $\begin{array}{l}\text { Rating } \\
\text { Score }\end{array}$ & $\begin{array}{l}\text { Target Vegetation } \\
\text { \% Ground Cover } \\
\text { (X) }\end{array}$ & $\begin{array}{l}\text { Target Vegetation } \\
\text { Distribution Pattern } \\
\text { (Y) }\end{array}$ & $\begin{array}{l}\text { Target Vegetation } \\
\text { Plant Vigor } \\
\text { (Z) }\end{array}$ \\
\hline 1 & $0-5 \%$ & Solitary Plants & $\begin{array}{l}>80 \% \text { Development } \\
\text { Disruption }\end{array}$ \\
\hline 2 & $6-20 \%$ & Patches $<10 \mathrm{ft}^{2}$ & $60-79 \%$ \\
\hline 3 & $21-50 \%$ & Patches $10-100 \mathrm{ft}^{2}$ & $40-59 \%$ \\
\hline 4 & $51-75 \%$ & $\begin{array}{l}\text { Solid, } 12 \text { in. }-24 \text { in. } \\
\text { between plants }\end{array}$ & $20-39 \%$ \\
\hline 5 & $>76 \%$ & $\begin{array}{l}\text { Solid, < } 12 \text { in. between } \\
\text { plants }\end{array}$ & $0-19 \%$ \\
\hline
\end{tabular}

(This table is also included in the attachments.)

After site inspection, a rating in the form "X.Y.Z" is composed, with a score of 1 through 5 assigned for each criterion in the following sequence: \% ground cover $(\mathbf{X})$; distribution pattern $(\mathbf{Y})$; and plant vigor (Z).

For example, a site rated as "2.3.2" exhibits the following characteristics:

- $6 \%$ to $20 \%$ of the site is infested by target vegetation (weeds).

- Target vegetation is growing in patches ranging in size from 10 to $100 \mathrm{ft}^{2}$.

- The herbicide application impacts or controls the normal growth and development of 60 to $79 \%$ of the target vegetation on the site. 


\subsection{Findings and Recommendations}

At year end, VMO compiled evaluations from all active work sites to formulate recommendations for improving the effectiveness of vegetation management operations in FY 1995 and beyond. These recommendations vary considerably for individual sites/areas, ranging from maintaining the current vegetation management strategy to taking such measures as increasing the use of cultural control methods to reduce future need for chemical control measures. The fundamental recommendations compiled below will be referenced for specific sites evaluated in Section 3.0 of this report.

1. Status Quo - Proceed in FY 1995 as in FY 1994. The results of vegetation management conducted in FY 1994 were good, and success will continue with the same course of action.

2. Reduce application rate from a base rate to a lower maintenance rate. Sites that exhibited good control and fewer weeds require application of less herbicide. This routine reduces costs and the quantity of herbicides needed to achieve the desired level of control.

3. Adhere more closely to the prescribed application schedule. Herbicides have fairly narrow effective application windows. When the appropriate window is not prioritized and is missed, the effectiveness of the application is reduced and the desired level of control may not be achieved.

4. Closely oversee herbicide application operations to ensure proper application. A greater field presence to provide more oversight may be needed to ensure proper application rates and technique.

5. Alter chemical control technique by increasing herbicide application rate, changing the formulation, conducting follow-up applications, and other methods until the seed bank is reduced and a lower maintenance rate will achieve the desired level of control.

6. Improve site preparation (clean-up) prior to herbicide application. The site condition at the time of application greatly impacts overall effectiveness. Proper site preparation (e.g., removing weed skeletons, mowing) will increase the effectiveness of any given application.

7. Complete treatment prior to infestation by undesirable vegetation. The prevention of weed proliferation is simpler and more cost effective than the treatment of weeds after they have become established on a site. 
8. Exercise greater effort to gain access during appropriate application windows. Customer access support was much less than adequate during the appropriate application windows. Other work was prioritized ahead of herbicide applications, and in many cases, the applications still have not been completed. Sites that did not receive the prescribed application are exhibiting extensive weed growth, which leads to higher cleanup and herbicide costs.

9. Implement a higher degree of cultural control. A vegetation management program should balance all of the control techniques in order to achieve the highest degree of control. The planting of desirable vegetation (i.e., perennial grasses and sedges) helps provide competition for undesirable weed species. Measures should be incorporated into all activities that abrade sites where grasses and desirable plants are established, to restore the site and prevent weeds from infesting the site.

(These recommendations are also provided in the attachments.)

\subsection{EVALUATIONS}

\subsection{Overview}

The effectiveness of vegetation management operations efforts varied widely across the site. In the interest of readability, the more than 1,000 individual site names (e.g., 218-W-4C or 216-A-10) will not be listed and rated. Instead, the sites are arranged into customer groups. These groups are further divided into application areas.

Summary tables identify general location, application time frames, vegetation management effectiveness rating (as described in Section 2.1) and general recommendations to improve future results (as described in Section 2.2).

\subsection{Vended Ground Herbicide Application Services}

Program Description--The ground herbicide application vendor provided eight types of application services as described in Section 2.1 .

Evaluation--The vendor applied herbicides according to the schedule and achieved good results, with few exceptions. The tables that follow describe the sites treated in this program. For ease of comparison, the tables are also included in the attachments. 


\begin{tabular}{|c|c|c|c|}
\hline Location & $\begin{array}{c}\text { Application Date } \\
(1993) \\
\end{array}$ & $\begin{array}{c}\text { Effectiveness } \\
\text { Rating } \\
\end{array}$ & $\begin{array}{l}\text { Fiscal Year } 1995 \\
\text { Recommendation }\end{array}$ \\
\hline \multicolumn{4}{|c|}{ Vended Granular } \\
\hline 300 Area & October '93 & 1.1.1 & 1 \\
\hline \multicolumn{4}{|l|}{ PNL (300 Area) } \\
\hline 100-K Area* & October '93 & 1.1 .1 & 1 \\
\hline $\begin{array}{l}\text { Patrol Training } \\
\text { Academy }\end{array}$ & October '93 & 1.1.1 & 1 \\
\hline $\begin{array}{c}\text { Electrical } \\
\text { Substations } \\
\end{array}$ & November '93 & 1.1 .1 & 1 \\
\hline ISV & October '93 & 2.1.1 & 4,5 \\
\hline \multicolumn{4}{|c|}{ Vended Liquid } \\
\hline 100-K Area* & October '93 & 2.1 .1 & 4,5 \\
\hline 100-B Area* & October '93 & 3.2 .2 & 4,5 \\
\hline 100-D Area* & October '93 & 2.2 .1 & 4,5 \\
\hline 100-H Area* & October '93 & 2.1 .2 & 4,5 \\
\hline 100-F Area* & October '93 & 2.1 .2 & 4,5 \\
\hline 100-N Area & October '93 & 2.1 .1 & 1 \\
\hline 3000 Area & October '93 & 2.2 .1 & 4,5 \\
\hline Radio Maintenance & October '93 & 2.2 .2 & 4,5 \\
\hline 6290 Building & October '93 & 1.1 .1 & 1 \\
\hline 200E Pipe Yard & October '93 & 1.1.1 & 1 \\
\hline 400 Area & October '93 & 1.1 .1 & 1 \\
\hline $\begin{array}{l}\text { Patrol Training } \\
\text { Academy }\end{array}$ & October '93 & 1.1 .1 & $\cdot 1$ \\
\hline
\end{tabular}

* Radiation Area Remedial Action Program (RARA) funded sites 


\begin{tabular}{||c|c|c|c||}
\hline \multicolumn{4}{|c|}{ Vended Selective } \\
\hline \hline Location & $\begin{array}{c}\text { Application Date } \\
\mathbf{( 1 9 9 4 )}\end{array}$ & $\begin{array}{c}\text { Effectiveness } \\
\text { Rating }\end{array}$ & $\begin{array}{c}\text { Fiscal Year 1995 } \\
\text { Recommendation }\end{array}$ \\
\hline \hline Water Export Lines & May'94 & 1.1 .1 & 1 \\
\hline ISV & June '94 & 1.1 .1 & 1 \\
\hline Burial Grounds & July '94 & 2.2 .2 & 4,5 \\
\hline 2704HV & June/August '94 & 2.1 .1 & 4,5 \\
\hline WSCF & May/July '94 & 2.1 .1 & 4,5 \\
\hline 1163 Building & June '94 & 1.1 .1 & 1 \\
\hline ERA Sites & May '94 & 1.1 .1 & 1 \\
\hline \hline
\end{tabular}




\subsection{Miscellaneous Sites}

Program Description--These sites were identified by customers through the service request process. These sites were added to the schedule for treatment with residual and/or selective herbicides.

Evaluation--The applications were made on schedule with very good results.

\begin{tabular}{||c|c|c|c||}
\hline Location & $\begin{array}{c}\text { Application Date } \\
\text { (1994) }\end{array}$ & $\begin{array}{c}\text { Effectiveness } \\
\text { Rating }\end{array}$ & $\begin{array}{c}\text { Fiscal Year 1995 } \\
\text { Recommendation }\end{array}$ \\
\hline \hline \multicolumn{4}{|c|}{ Miscellaneous - Residual } \\
\hline 216-Z-1A & January '94 & 1.1 .1 & $1,3,5$ \\
\hline $216-Z-9$ & January '94 & 1.1 .1 & $1,3,5$ \\
\hline \hline \multicolumn{4}{|c|}{ Miscellaneous - Selective } \\
\hline PNL (ALE Site) & June '94 & 1.1 .1 & $3,4,5,6$ \\
\hline US West & August '94 & 1.1 .1 & $3,4,5,6$ \\
\hline 200-UP-1 & June '94 & 1.1 .1 & $3,4,5,6$ \\
\hline Modu-tanks & July '94 & 1.1 .1 & $3,4,5,6$ \\
\hline In-Situ & July '94 & 1.1 .1 & $3,4,5,6$ \\
Bio-Remediation & July '94 & 1.1 .1 & $3,4,5,6$ \\
\hline 200-ZP-1 & August '94 & 1.1 .1 & $3,4,5,6$ \\
\hline Drilling Technology & \multicolumn{1}{c||}{} \\
\hline
\end{tabular}

\subsection{Rights of Way}

Program Description--For the purpose of this report, the following classes of sites will be considered "rights-of-way":
- $\quad$ Roád sides
- Fencelines
- Railroad beds
- $\quad$ Steam lines. 
Water export lines and electrical utilities (substations and tranșfer lines) were treated by the ground vendor and are evaluated in Section 3.2 of this report.

In right-of-way vegetation management there are three primary control zones (see Figure 3 for illustrations):

- Zone 1 - Infiltration Zone: From the primary transport surface to the bottom of the drainage ditch. Targeted for bare-ground applications to allow water infiltration and prevent the degradation of the primary transport zone by encroaching plants.

- Zone 2 - Transition Zone: From the bottom of the drainage ditch to the border of the indigenous zone. Targeted for selective weed control, with the intent of treating target vegetation (e.g., deep-rooted vegetation, line-of-sight-obscuring vegetation, noxious weeds) and leaving the desirable grasses.

- $\quad$ Zone 3 - Indigenous Zone: From the transition zone to the natural fauna along the right-of-way. Targeted for low impact or no treatments.

Evaluation--Generally, all areas were treated on schedule except for railroads. This area did not receive treatment during the selective windows because of equipment breakdowns. 


\begin{tabular}{|c|c|c|c|}
\hline Location & Application Date & $\begin{array}{l}\text { Effectiveness } \\
\text { Rating }\end{array}$ & $\begin{array}{l}\text { Fiscal Year } 1995 \\
\text { Recommendation }\end{array}$ \\
\hline \multicolumn{4}{|c|}{ Rights of Way - Residual } \\
\hline $\begin{array}{c}600 \text { Area } \\
\text { Primary Roads } \\
\end{array}$ & $\begin{array}{l}\text { October '93/ } \\
\text { February '94 } \\
\end{array}$ & 1.2.1 & $3,4,5,6,7$ \\
\hline $\begin{array}{c}600 \text { Area } \\
\text { Secondary Roads }\end{array}$ & February/March '94 & 1.2.1 & $3,4,5,6,7$ \\
\hline Railroads & October '94 & 2.2 .3 & $3,4,5,6,7$ \\
\hline 200 Area Roads & January/March '94 & 1.2.1 & 3,4 \\
\hline $\begin{array}{c}\text { Steam line (200E to } \\
200 \mathrm{~W})\end{array}$ & February '94 & 1.1 .1 & $1,3,5$ \\
\hline $\begin{array}{l}200 \text { Area Grounds } \\
\text { and Parking Lots }\end{array}$ & $\begin{array}{l}\text { November '93/ } \\
\text { March '94 }\end{array}$ & 1.2 .1 & 3,4 \\
\hline $\begin{array}{c}200 \text { Area Security } \\
\text { Fence Lines }\end{array}$ & February '94 & 1.2 .1 & 3,4 \\
\hline \multicolumn{4}{|c|}{ Rights of Way - Selective } \\
\hline $\begin{array}{c}600 \text { Area } \\
\text { Primary Roads }\end{array}$ & $\begin{array}{l}\text { April-August } \\
\text { '94 }\end{array}$ & 2.2 .3 & $3,4,5,6$ \\
\hline $\begin{array}{c}600 \text { Area } \\
\text { Secondary Roads }\end{array}$ & $\begin{array}{l}\text { April-August } \\
\text { 'YR? }\end{array}$ & 2.2 .3 & $3,4,5,6,7$ \\
\hline Railroads & No Applications & 3.3.5 & 7 \\
\hline 200 Area Roads & $\begin{array}{l}\text { April-August } \\
\text { '94 }\end{array}$ & 1.2 .1 & $3,4,5$ \\
\hline $\begin{array}{l}200 \text { Area Grounds } \\
\text { and Parking Lots }\end{array}$ & $\begin{array}{l}\text { April-August } \\
\text { '94 }\end{array}$ & 1.2 .1 & $3,4,5$ \\
\hline $\begin{array}{l}200 \text { Area Security } \\
\text { Fence Lines }\end{array}$ & $\begin{array}{l}\text { April-August } \\
\text { '94 }\end{array}$ & 1.2 .1 & 3,4 \\
\hline
\end{tabular}




\subsection{Active Burial Grounds}

Program Description--The sites associated with Active Burial Grounds (ABG) required both residual non-selective treatment and non-residual selective treatment. Locations such as the Central Waste Complex, Sodium Storage, and the 616 Temporary Storage Facility were targeted for bare-ground treatment in parking lots and around storage buildings. Burial grounds were scheduled for selective herbicide applications.

The majority of the ABG sites were scheduled for aerial applications. These sites were scheduled for four applications during the season. A more detailed summary of the Aerial Program is provided in Section 4.0.

Evaluation--With some exceptions, the level of control achieved on ABG sites was very good. The aerial applications were not as effective as ground applications. Most sites were treated by VMO with ground application equipment, which resulted in better weed control.

\begin{tabular}{||c|c|c|c||}
\hline Location & Application Date & $\begin{array}{c}\text { Effectiveness } \\
\text { Rating }\end{array}$ & $\begin{array}{c}\text { Fiscal Year 1995 } \\
\text { Recommendation }\end{array}$ \\
\hline \hline \multicolumn{4}{|c||}{ Active Burial Grounds - Residual } \\
\hline $\begin{array}{c}\text { Central Waste } \\
\text { Complex }\end{array}$ & November'93 & 1.1 .1 & 3,5 \\
\hline Satellite Sites & November '93 & 1.1 .1 & 3,5 \\
\hline \hline \multicolumn{4}{|c||}{ Active Burial Grounds - Selective } \\
\hline $\begin{array}{c}\text { Burial Grounds } \\
\text { (Ground App.) }\end{array}$ & $\begin{array}{c}\text { April-August } \\
\text { '94 }\end{array}$ & 1.2 .1 & 3,5 \\
\hline $\begin{array}{c}\text { Burial Grounds } \\
\text { (Aerial) }\end{array}$ & $\begin{array}{c}\text { April-August } \\
\text { '94 }\end{array}$ & 4.3 .4 & $3,4,5,6$ \\
\hline
\end{tabular}

\subsection{Waste Tank Operations}

Program Description--The types of application and the degree of control exhibited within Waste Tank Operations (WTO) varied considerably. Evaluation (by application type) is as follows:

Sites requiring non-selective residual weed control measures, including: 
- $\quad$ All of the tank farms complexes

- $\quad$ Some of the diversion boxes

- The grout facilities

- The recently stabilized portion of 216-U-14.

Sites requiring selective non-residual weed control measures, including:

- Most of the active cribs

- $\quad$ Active covered transfer ditches or lines

- The remaining diversion boxes.

Sites requiring non-selective, non-residual weed control, including (sites were addressed as aquatic sites):

- $\quad$ Open, flowing ditches

- $\quad$ Open ponds containing water.

Evaluation--The level of control achieved in WTO sites was very good. However, future problems are anticipated resulting from soil adhesives applied at the WTO sites. A greater effort will be made to coordinate the herbicide applications with the soil adhesive applications.

\begin{tabular}{||c|c|c|c||}
\hline \multicolumn{4}{|c|}{ Waste Tank Operations - Residual } \\
\hline \hline Location & Application Date & $\begin{array}{c}\text { Effectiveness } \\
\text { Rating }\end{array}$ & $\begin{array}{c}\text { Fiscal Year 1995 } \\
\text { Recommendation }\end{array}$ \\
\hline \hline A Tank Farms & October '93 & 1.1 .1 & 3,8 \\
\hline B Tank Farms & October '93 & 1.1 .1 & 3,8 \\
\hline C Tank Farms & October '93 & 1.1 .1 & 3,8 \\
\hline S Tank Farms & October '93 & 1.1 .1 & 3,8 \\
\hline T Tank.Farms & October '93 & 1.1 .1 & 3,8 \\
\hline U Tank Farms & October '93 & 1.1 .1 & 3,8 \\
\hline Grout Treatment & October '93 & 1.1 .1 & 3 \\
\hline Grout (Dry) & October '93 & 1.1 .1 & 3 \\
\hline $\begin{array}{c}\text { 216-U-14 } \\
\text { (Stabilized) }\end{array}$ & November '93 & 1.1 .1 & 3 \\
\hline
\end{tabular}




\begin{tabular}{|c|c|c|c||}
\hline \multicolumn{4}{|c|}{ Waste Tank Operations - Selective } \\
\hline \hline Location & Application Date & $\begin{array}{c}\text { Effectiveness } \\
\text { Rating }\end{array}$ & $\begin{array}{c}\text { Fiscal Year 1995 } \\
\text { Recommendation }\end{array}$ \\
\hline \hline $\begin{array}{c}\text { 216-U-14 } \\
\text { (Stabilized) }\end{array}$ & $\begin{array}{c}\text { Spring/Summer } \\
\text { '94 }\end{array}$ & 1.1 .1 & 3 \\
\hline $\begin{array}{c}200 \text { Area Active } \\
\text { Cribs }\end{array}$ & $\begin{array}{c}\text { Spring/Summer } \\
\text { '94 }\end{array}$ & 1.1 .1 & 3 \\
\hline $\begin{array}{c}200 \text { Area Open } \\
\text { Ditches and Ponds }\end{array}$ & $\begin{array}{c}\text { Spring/Summer } \\
\text { '94 }\end{array}$ & 1.1 .1 & 3 \\
\hline
\end{tabular}

\subsection{Radiation Area Remedial Action}

Program Description--The RARA sites were divided into two main groups: (1) those to be treated with residual herbicides (to maintain bare ground), and (2) those to be treated with selective herbicides (to assist in promoting existing grass stands). Because of the extensive geographic distribution, the sites were further divided into the 100 and 200 Areas.

The 100 Area RARA sites are primarily stone cobble and were scheduled for non-selective residual herbicide applications. Sites are further divided into two types of radiologically controlled areas (RCAs): (1) surface contaminated RCAs, and (2) underground RCAs. The surface contaminated RCAs were treated by WHC personnel, and all underground RCAs were treated by a ground vendor. These sites all have good control with a few exceptions in the 100 $\mathrm{B} / \mathrm{C}$ Area.

The 200 Area RARA sites are predominately re-vegetated sites where it is desirable to encourage stronger stands of perennial grasses. These sites were scheduled to be treated with selective non-residual herbicides. A few sites are bare ground and were scheduled to be applied with non-selective residual herbicides. The selective herbicide applications were divided into two types: (1) aerial vendor and (2) WHC ground application. Aerial applications were changed from three application windows to four to increase the control of deep-rooted vegetation. The aerial vendor was scheduled to treat approximately 750 acres, and WHC personnel were to treat the balance with ground applications.

Evaluation--With a few exceptions, the level of control on all RARA sites was good. The first selective herbicide application (both ground and aerial) was completed by WHC personnel. The second application was completed by both the aerial vendor and WHC personnel as scheduled. The third application window was completed with $80 \%$ of the aerial acres completed by WHC 
personnel. The fourth application window was completed by WHC personnel using ground application. The increase in productivity by WHC personnel did not decrease the effectiveness of herbicide applications. Equipment upgrades and continued improvements in timing of applications will continue to improve the effectiveness of herbicide applications in FY 1995. In FY 1995, VMO plans to redistribute the 100 Areas RARA sites for treatment by WHC personnel.

\begin{tabular}{|c|c|c|c|}
\hline Location & Application Date & $\begin{array}{c}\text { Effectiveness } \\
\text { Rating }\end{array}$ & $\begin{array}{l}\text { Fiscal Year } 1995 \\
\text { Recommendation }\end{array}$ \\
\hline \multicolumn{4}{|c|}{ Radiation Area Remedial Action - Residual } \\
\hline $\begin{array}{c}100 \text { Areas Surface } \\
\text { RCAs }\end{array}$ & October '93 & 1.1.1 & 3 \\
\hline $\begin{array}{c}100 \text { Areas } \\
\text { Underground RCAs }\end{array}$ & October '93 & 1.1 .1 & 3 \\
\hline 200 Area Sites & October '93 & 1.1.1 & 3 \\
\hline \multicolumn{4}{|c|}{ Radiation Area Remedial Action - Selective (200 Areas) } \\
\hline First Round & March '94 & 1.1.1 & 3,5 \\
\hline Second Round & May '94 & 1.1.1 & 3 \\
\hline Third Round & July '94 & 1.1.1 & 3 \\
\hline Fourth Round & September '94 & 1.1 .1 & 3 \\
\hline
\end{tabular}

\subsection{AERIAL}

\subsection{Overview}

Acreage from three separate programs was included in the FY 1994 aerial program. Approximately 1,200 acres were treated with four separate applications. Sites that previously had unsatisfactory results were included in this year's aerial herbicide application program. The scheduled acres were distributed as follows:

- $\quad$ RARA approximately $65 \%$

- $\quad$ ABG approximately $25 \%$

- WTO approximately $10 \%$. 
Aerial application sites were monitored throughout the season to assess the effectiveness of the four selective herbicide applications. A new herbicide deposition aid was employed for all applications.

The level of control achieved with the aerial program in FY 1994 was below expectations compared to previous years. Sites in both $200 \mathrm{E}$ and $200 \mathrm{~W}$ exhibited low levels of control. This was mitigated using ground applications. The table below shows the poor effectiveness of aerial applications compared to ground applications, which more effectively controlled deep-rooted vegetation.

\begin{tabular}{||c|c|c|c||}
\hline \multicolumn{4}{|c|}{ Aerial Application Program } \\
\hline \hline Location & Application Date & $\begin{array}{c}\text { Effectiveness } \\
\text { Rating }\end{array}$ & $\begin{array}{c}\text { Fiscal Year 1995 } \\
\text { Recommendation }\end{array}$ \\
\hline \hline First Round & No Application & & $3,4,5$ \\
\hline Second Round & $\begin{array}{c}\text { May '94 (100\% } \\
\text { Acreage) }\end{array}$ & 4.4 .4 & $3,4,5$ \\
\hline Third Round & $\begin{array}{c}\text { July '94 (20\% of } \\
\text { Acreage) }\end{array}$ & 4.4 .4 & \\
\hline Fourth Round & No Application & & \\
\hline
\end{tabular}

\subsection{SUMMARY}

In FY 1994, more than 6,000 acres were treated with a variety of herbicides. The total number of acres can be somewhat misleading, because some areas were treated more than once.

Herbicide application activities that were scheduled for completion in FY 1994 were approximately $95 \%$ complete by the close of the year. However, the work that was not completed was not in high-priority/high-profile sites such as road shoulders, active cribs, ponds, ditches, or tank farms.

A recap of all the effectiveness ratings is illustrated in Figure 4, which compares the total occurrences of any given score. The ratings are color coded by each of the three evaluation criteria. The data indicate a predominantly effective season with a failure rate of less than $5 \%$, mostly in areas where no application was made at all. 
The two most recurrent recommendations/difficulties are (1) the lack of adherence to prescribed application schedules by the performing units, and (2) A need to alter chemical control techniques by increasing application rate, changing formulation or conducting followup application to achieve the desired level of control. The recommendations for the Hanford Site as a whole are summarized in Figure 5 as a percentage of the total number of recommendations compiled for all sites combined.

All of the work actually contracted to be performed by vendors was completed on schedule. Although the aerial program had low effectiveness, the applications were completed as scheduled.

VMO experienced many changes in FY 1994. The majority of the changes have had a positive impact on the effective management of vegetation on the Hanford Site. VMO will continue to evolve to remain current with the regulatory and technical changes within the industry. Continuous improvements will be made to increase program effectiveness. 
Figure 1. Primary Control Methods.

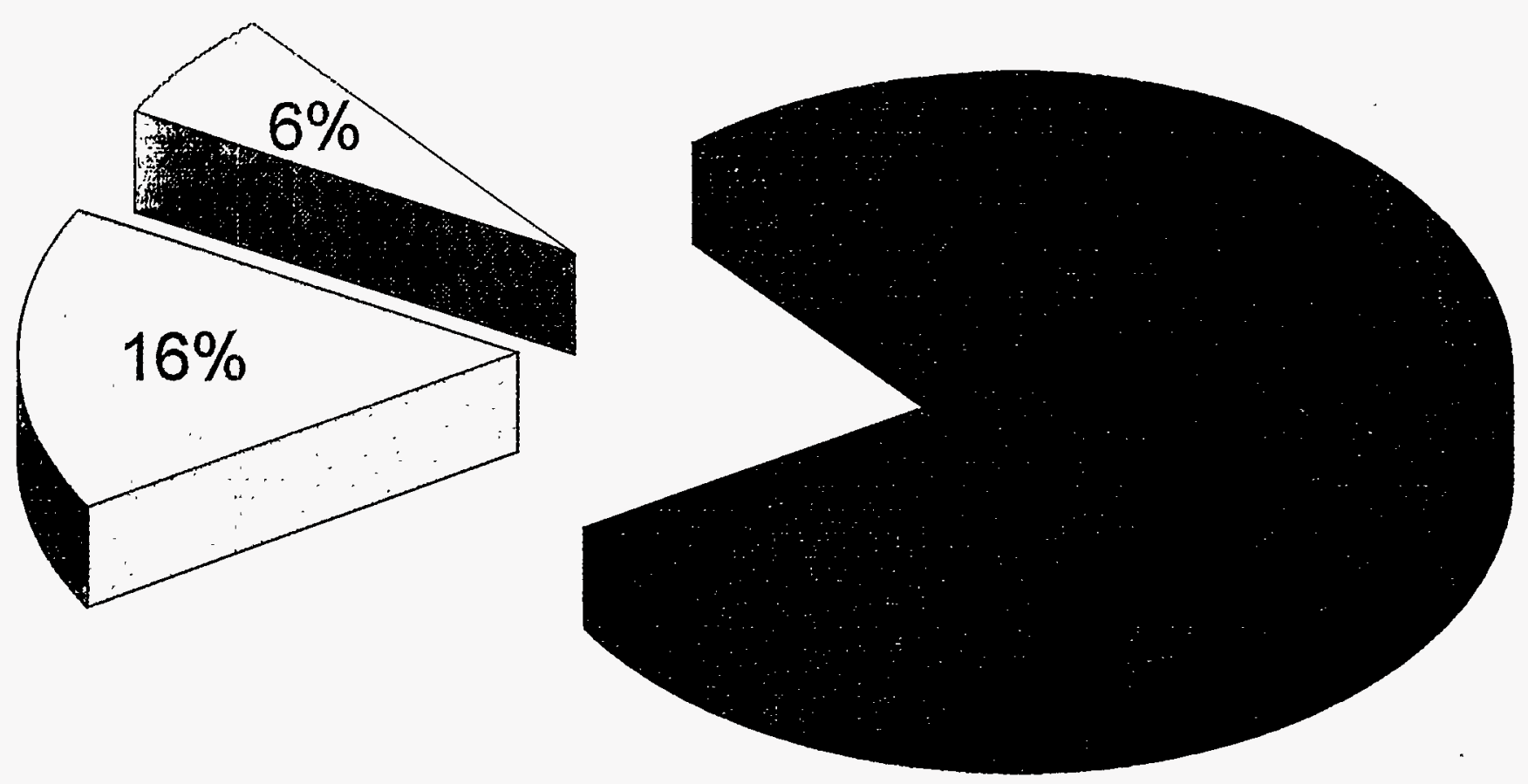

\section{Control Methods}

$\square$ CULTURAL $\square$ MRCHANDAL D OHEMCAL 
Figure 2. Primary Control Techniques.

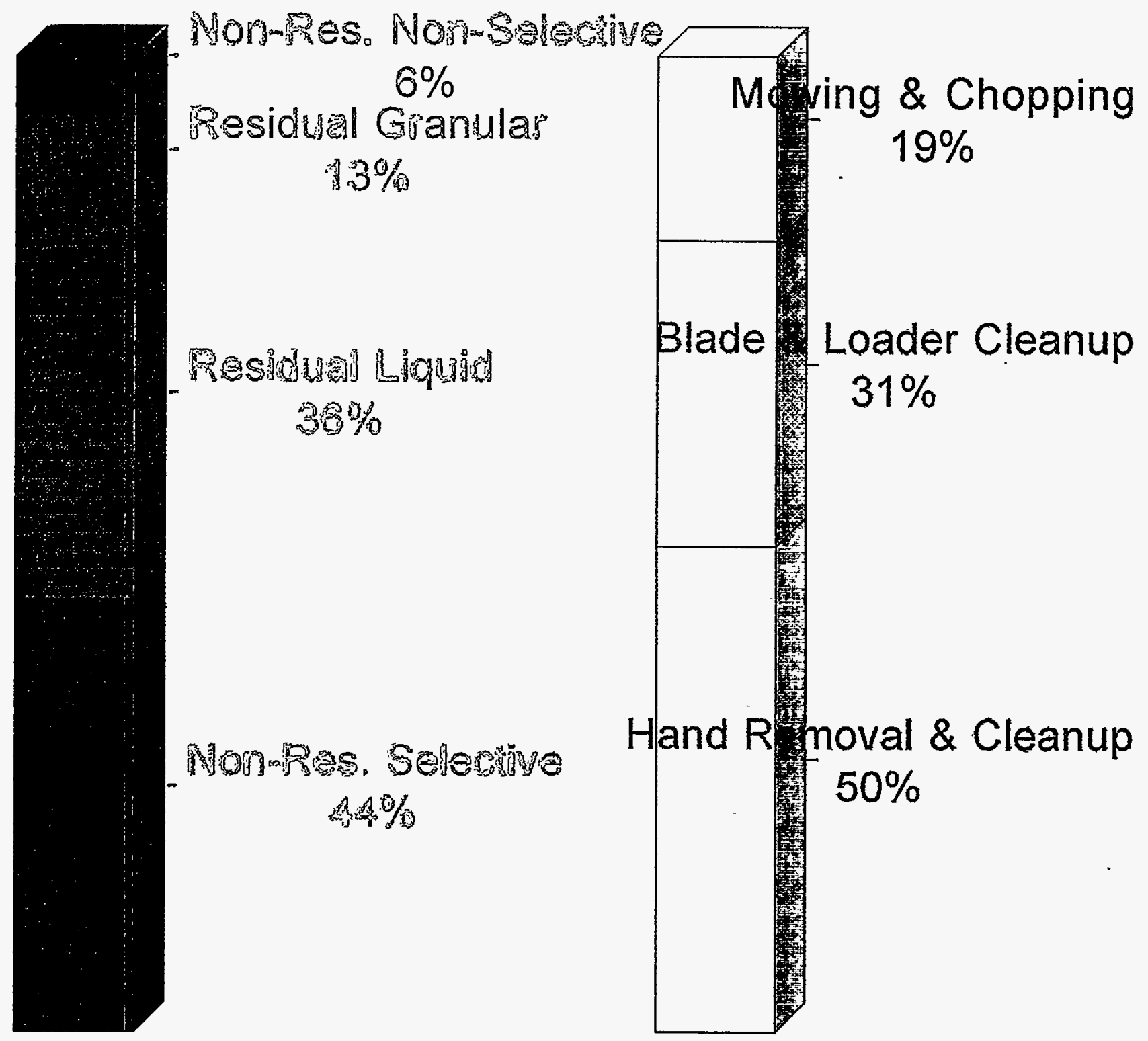

\section{Chemical Mechanical}


Figure 3. Right of Way Zones.

- ZONE \# 1

䠣 ZONE \# 2

ZONE \# 3
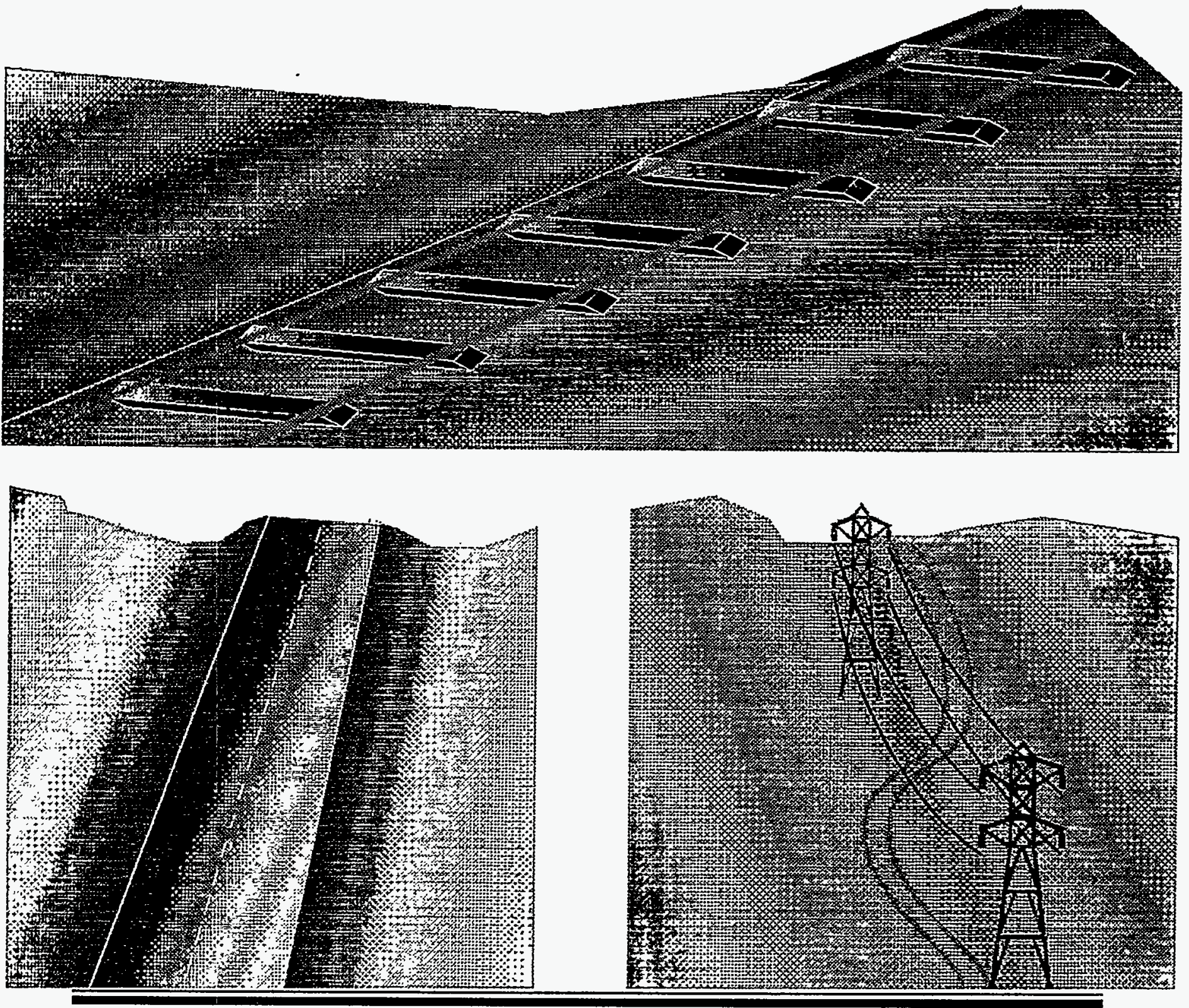
Figure 4. Evaluation Summary.

Frequency

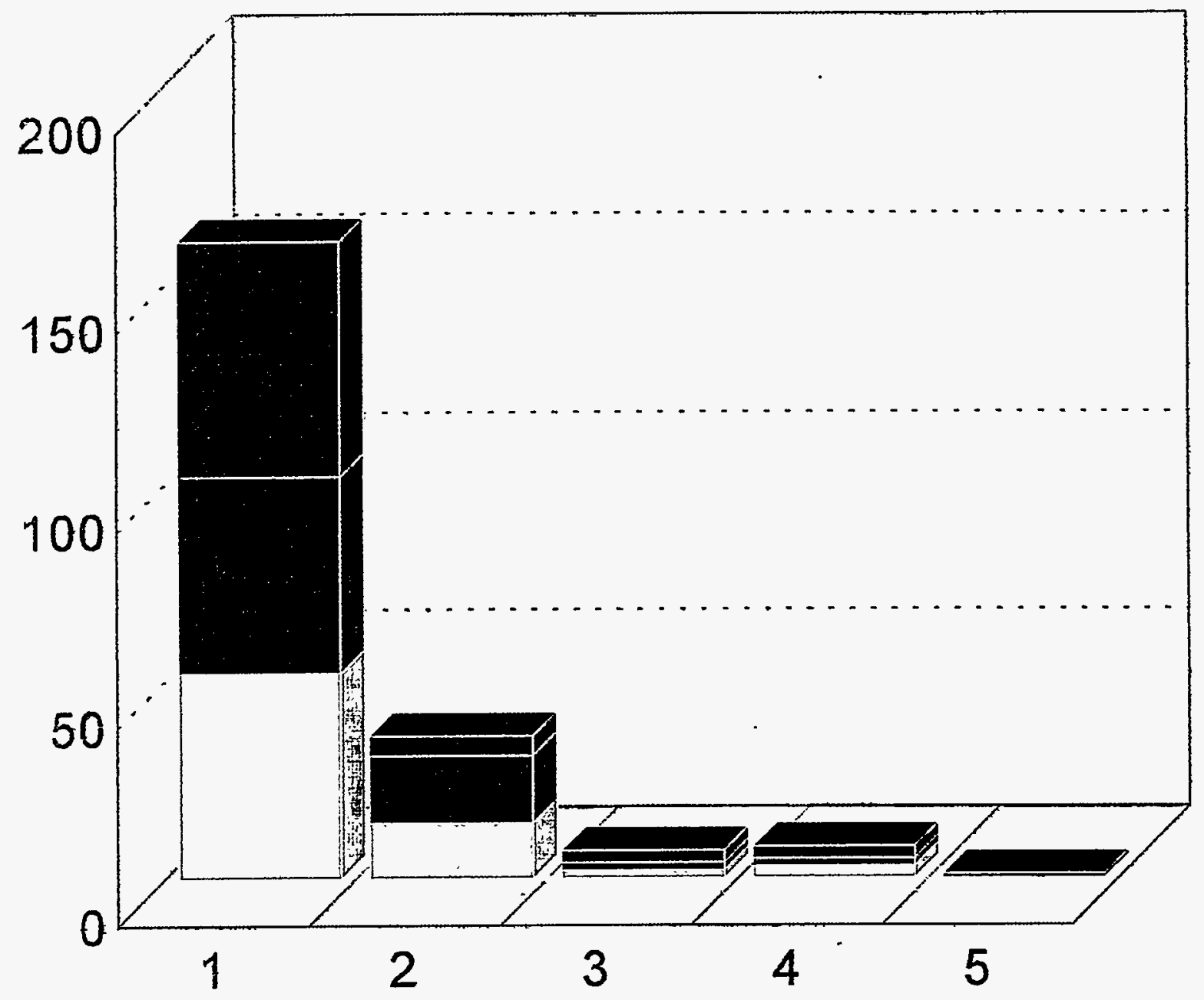

Rating Vahues

\section{Evaluation Criteria}

$\square \%$ Ground Cover Distribution Plant Vigor 
Figure 5. Recommendations Summary.

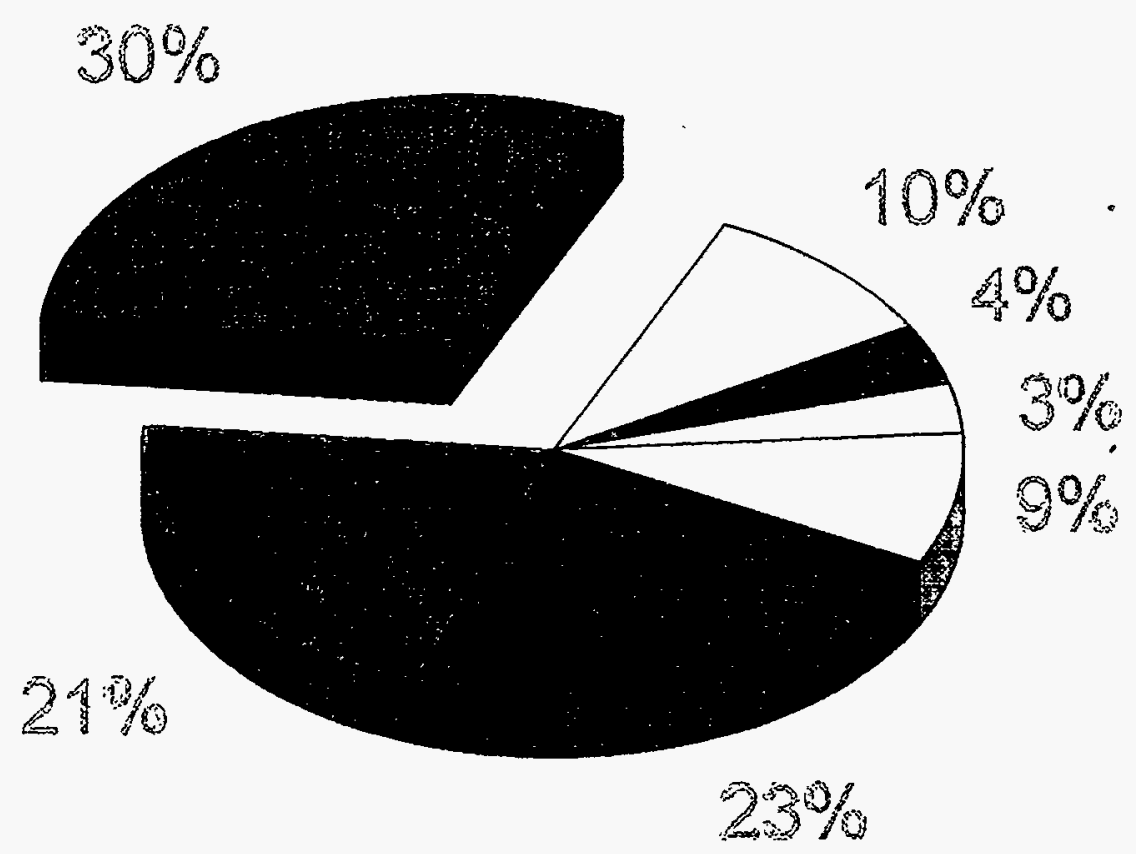

Findings and Recommendation

$\square$ Status Quo $\quad$ Schedule Variances

More Supervision Change Material

$\square$ Better Preparations $\square$ Treat Sooner

Gain Access 
ATTACHMENTS 
This page intentionally left blank. 


\section{Vegetation Management Effectiveness}

\begin{tabular}{||c|l|l|l||}
\hline \hline $\begin{array}{c}\text { Rating } \\
\text { Score }\end{array}$ & $\begin{array}{c}\text { Target Vegetation } \\
\% \text { Ground Cover } \\
(\mathbf{X})\end{array}$ & \multicolumn{1}{|c|}{$\begin{array}{c}\text { Target Vegetation } \\
\text { Distribution Pattern } \\
(\mathbf{Y})\end{array}$} & $\begin{array}{c}\text { Target Vegetation } \\
\text { Plant Vigor } \\
(\mathbf{Z})\end{array}$ \\
\hline \hline 1 & $0-5 \%$ & Solitary Plants & $\begin{array}{l}>80 \% \text { Development } \\
\text { Disruption }\end{array}$ \\
\hline 2 & $6-20 \%$ & Patches < $10 \mathrm{ft}^{2}$ & $60-79 \%$ \\
\hline 3 & $21-50 \%$ & Patches $10-100 \mathrm{ft}^{2}$ & $40-59 \%$ \\
\hline 4 & $51-75 \%$ & $\begin{array}{l}\text { Solid, } 12 \text { in. }-24 \text { in. } \\
\text { between plants }\end{array}$ & $20-39 \%$ \\
\hline 5 & $-76 \%$. & $\begin{array}{l}\text { Solid, with < } 12 \text { in. } \\
\text { between plants }\end{array}$ & $0-19 \%$ \\
\hline
\end{tabular}

After site inspection, a rating in the form "X.Y.Z" is composed, with a score of 1 through 5 assigned for each criterion in the following sequence: $\%$ ground cover $(\mathbf{X})$; distribution pattern $(\mathbf{Y})$; and plant vigor (Z).

For example, a site rated as "2.3.2" exhibits the following characteristics:

- $6 \%$ to $20 \%$ of the site is infested by target vegetation (weeds).

- Target vegetation is growing in patches ranging in size from 10 to $100 \mathrm{ft}^{2}$.

- The herbicide application impacts or controls the normal growth and development of 60 to $79 \%$ of the target vegetation on the site.

\section{Recommendations:}

1. Status Quo - Proceed in FY 1995 as in FY 1994. The results of vegetation management conducted in FY 1994 were good, and success will continue with the same course of action. 
2. Reduce application rate from a base rate to a lower maintenance rate. Sites that exhibited good control and fewer weeds require application of less herbicide. This routine reduces costs and the quantity of herbicides needed to achieve the desired level of control.

3. Adhere more closely to the prescribed application schedule. Herbicides have fairly narrow effective application windows. When the appropriate window is not prioritized and is missed, the effectiveness of the application is reduced and the desired level of control may not be achieved.

4. Closely oversee herbicide application operations to ensure proper application. A greater field presence to provide more oversight may be needed to ensure proper application rates and technique.

5. Alter chemical control technique by increasing herbicide application rate, changing the formulation, conducting follow-up applications, and other methods until the seed bank is reduced and a lower maintenance rate will achieve the desired level of control.

6. Improve site preparation (clean-up) prior to herbicide application. The site condition at the time of application greatly impacts overall effectiveness. Proper site preparation (e.g., removing weed skeletons, mowing) will increase the effectiveness of any given application.

7. Complete treatment prior to undesirable vegetation infestation. The prevention of weed proliferation is simpler and more cost effective than the treatment of weeds after they have become established on a site.

8. Exercise greater effort to gain access during appropriate application windows. Customer access support was much less than adequate during the appropriate application windows. Other work was prioritized ahead of herbicide applications, and in many cases, the applications still have not been completed. Sites that did not receive the prescribed application are exhibiting extensive weed growth, which leads to higher clean-up and herbicide costs.

9. Implement a higher degree of cultural control. A vegetation management program should balance all of the control techniques in order to achieve the highest degree of control. The planting of desirable vegetation (i.e., perennial grasses and sedges) helps provide competition for undesirable weed species. Measures should be incorporated into all activities that abrade sites where grasses and desirable plants are established, to restore the site and prevent weeds from infesting the site. 


\section{VENDED GRANULAR}

\begin{tabular}{|c|c|c|c||}
\hline LOCATION & $\begin{array}{c}\text { APPLICATION } \\
\text { DATE }\end{array}$ & $\begin{array}{c}\text { EFFECTIVENESS } \\
\text { RATING }\end{array}$ & $\begin{array}{c}\text { FISCAL YEAR 1995 } \\
\text { RECOMMENDATION }\end{array}$ \\
\hline \hline 300 AREA & OCTOBER '93 & 1.1 .1 & 1 \\
\hline PNL (300A) & & & 1 \\
\hline $\begin{array}{c}\text { 100-K AREA* } \\
\text { PATROL } \\
\text { TRAINING } \\
\text { ACADEMY }\end{array}$ & OCTOBER '93 & 1.1 .1 & 1 \\
\hline $\begin{array}{c}\text { ELECTRICAL } \\
\text { SUBSTATIONS }\end{array}$ & NOVEMBER '93 & 1.1 .1 & 1 \\
\hline ISV & OCTOBER '93 & 2.1 .1 & 4,5 \\
\hline
\end{tabular}


VENDED LIQUID

\begin{tabular}{||c|c|c|c||}
\hline LOCATION & $\begin{array}{c}\text { APPLICATION } \\
\text { DATE }\end{array}$ & $\begin{array}{c}\text { EFFECTIVENESS } \\
\text { RATING }\end{array}$ & $\begin{array}{c}\text { FISCAL YEAR 1995 } \\
\text { RECOMMENDATION }\end{array}$ \\
\hline \hline 100-K AREA* & OCTOBER '93 & 2.1 .1 & 4,5 \\
\hline 100-B AREA* & OCTOBER '93 & 3.2 .2 & 4,5 \\
\hline 100-D AREA* & OCTOBER '93 & 2.2 .1 & 4,5 \\
\hline 100-H AREA* & OCTOBER '93 & 2.1 .2 & 4,5 \\
\hline 100-F AREA* & OCTOBER'93 & 2.1 .2 & 4,5 \\
\hline 100-N AREA & OCTOBER '93 & 2.1 .1 & 1 \\
\hline 3000 AREA & OCTOBER '93 & 2.2 .1 & 4,5 \\
\hline $\begin{array}{c}\text { RADIO } \\
\text { MAINTENANCE }\end{array}$ & OCTOBER '93 & 2.2 .2 & 1 \\
\hline 6290 BUILDING & OCTOBER '93 & 1.1 .1 & 1 \\
\hline 200E PIPE YARD & OCTOBER'93 & 1.1 .1 & 1 \\
\hline 400 AREA & OCTOBER '93 & 1.1 .1 & 1 \\
\hline $\begin{array}{c}\text { PATROL } \\
\text { TRAINING } \\
\text { ACADEMY }\end{array}$ & OCTOBER '93 & 1.1 .1 & \\
\hline \hline
\end{tabular}

* Radiation Area Remedial Action Program (RARA) funded sites 
VENDED SELECTIVE

\begin{tabular}{|c|c|c|c|}
\hline LOCATION & $\begin{array}{c}\text { APPLICATION } \\
\text { DATE }\end{array}$ & $\begin{array}{c}\text { EFFECTIVENESS } \\
\text { RATING }\end{array}$ & $\begin{array}{c}\text { FISCAL YEAR 1995 } \\
\text { RECOMMENDATION }\end{array}$ \\
\hline \hline $\begin{array}{c}\text { WATER EXPORT } \\
\text { LINES }\end{array}$ & MAY '94 & 1.1 .1 & 1 \\
\hline ISV & JUNE '94 & 1.1 .1 & 1 \\
\hline $\begin{array}{c}\text { BURIAL } \\
\text { GROUNDS }\end{array}$ & JULY '94 & 2.2 .2 & 4,5 \\
\hline 2704HV & JUNE/AUGUST'94 & 2.1 .1 & 4,5 \\
\hline WSCF & MAY/JULY'94 & 2.1 .1 & 1 \\
\hline 1163 BUILDING & JUNE '94 & 1.1 .1 & 1 \\
\hline ERA SITES & MAY '94 & 1.1 .1 & .5 \\
\hline
\end{tabular}

MISC. - RESIDUAL

\begin{tabular}{||c|c|c|c||}
\hline \hline LOCATION & $\begin{array}{c}\text { APPLICATION } \\
\text { DATE }\end{array}$ & $\begin{array}{c}\text { EFFECTIVENESS } \\
\text { RATING }\end{array}$ & $\begin{array}{c}\text { FISCAL YEAR 1995 } \\
\text { RECOMMENDATION }\end{array}$ \\
\hline \hline $216-Z-1 A$ & JANUARY'94 & 1.1 .1 & $1,3,5$ \\
\hline $216-Z-9$ & JANUARY'94 & 1.1 .1 & $1,3,5$ \\
\hline
\end{tabular}




\section{MISC. - SELECTIVE}

\begin{tabular}{||c|c|c|c||}
\hline LOCATION & $\begin{array}{c}\text { APPLICATION } \\
\text { DATE }\end{array}$ & $\begin{array}{c}\text { EFFECTIVENESS } \\
\text { RATING }\end{array}$ & $\begin{array}{c}\text { FISCAL YEAR 1995 } \\
\text { RECOMMENDATION }\end{array}$ \\
\hline \hline PNL (ALE SITE) & JUNE '94 & 1.1 .1 & $3,4,5,6$ \\
\hline US WEST . & AUGUST'94 & 1.1 .1 & $3,4,5,6$ \\
\hline 200 UP-1 & JUNE '94 & 1.1 .1 & $3,4,5,6$ \\
\hline MODU-TANKS & JULY'94 & 1.1 .1 & $3,4,5,6$ \\
\hline IN-SITU & JULY' '94 & 1.1 .1 & $3,4,5,6$ \\
BIO-REMEDIATIO & & & $3,4,5,6$ \\
\hline N & & 1.1 .1 & $3,4,5,6$ \\
\hline 200 ZP-1 & JULY'94 & 1.1 .1 & \\
\hline DRILLING TECH. & AUGUST'94 & & \\
\hline
\end{tabular}


RIGHTS OF WAY - RESIDUAL

\begin{tabular}{|c|c|c|c|}
\hline LOCATION & $\begin{array}{l}\text { APPLICATION } \\
\text { DATE }\end{array}$ & $\begin{array}{c}\text { EFFECTIVENESS } \\
\text { RATING }\end{array}$ & $\begin{array}{l}\text { FISCAL YEAR } 1995 \\
\text { RECOMMENDATION }\end{array}$ \\
\hline $\begin{array}{c}600 \text { Area } \\
\text { Primary Roads }\end{array}$ & $\begin{array}{l}\text { OCTOBER '93/ } \\
\text { FEBRUARY '94 }\end{array}$ & 1.2 .1 & $3,4,5,6,7$ \\
\hline $\begin{array}{c}600 \text { Area } \\
\text { Secondary Roads }\end{array}$ & $\begin{array}{c}\text { FEBRUARY/MAR } \\
\text { CH ' } 94\end{array}$ & 1.2 .1 & $3,4,5,6,7$ \\
\hline Railroads & OCTOBER '94 & 2.2 .3 & $3,4,5,6,7$ \\
\hline 200 Area Roads & $\begin{array}{c}\text { JANUARY/MARC } \\
\text { H' '94 } \\
\end{array}$ & 1.2.1 & 3,4 \\
\hline $\begin{array}{l}\text { Steam Line (200E } \\
\text { to } 200 \mathrm{~W})\end{array}$ & FEBRUARY '94 & 1.1 .1 & $1,3,5$ \\
\hline $\begin{array}{l}200 \text { Area Grounds } \\
\text { and Parking Lots }\end{array}$ & $\begin{array}{c}\text { NOVEMBER '93/ } \\
\text { MARCH '94 }\end{array}$ & 1.2 .1 & 3,4 \\
\hline $\begin{array}{l}200 \text { Area Security } \\
\text { Fence Lines }\end{array}$ & FEBRUARY '94 & 1.2 .1 & 3,4 \\
\hline
\end{tabular}




\section{RIGHTS OF WAY - SELECTIVE}

\begin{tabular}{||c|c|c|c||}
\hline LOCATION & $\begin{array}{c}\text { APPLICATION } \\
\text { DATE }\end{array}$ & $\begin{array}{c}\text { EFFECTIVENESS } \\
\text { RATING }\end{array}$ & $\begin{array}{c}\text { FISCAL YEAR 1995 } \\
\text { RECOMMENDATION }\end{array}$ \\
\hline \hline $\begin{array}{c}600 \text { Area } \\
\text { Primary Roads }\end{array}$ & $\begin{array}{c}\text { APRIL-AUGUST } \\
\text { '94 }\end{array}$ & 2.2 .3 & $3,4,5,6$ \\
\hline $\begin{array}{c}600 \text { Area } \\
\text { Secondary Roads }\end{array}$ & $\begin{array}{c}\text { APRIL-AUGUST } \\
\text { '94 }\end{array}$ & 2.2 .3 & $3,4,5,6,7$ \\
\hline Railroads & $\begin{array}{c}\text { NO } \\
\text { APPLICATIONS }\end{array}$ & 3.3 .5 & 7 \\
\hline 200 Area Roads & $\begin{array}{c}\text { APRIL-AUGUST } \\
\text { '94 }\end{array}$ & 1.2 .1 & $3,4,5$ \\
\hline $\begin{array}{c}\text { 200 Area Grounds } \\
\text { and Parking Lots }\end{array}$ & $\begin{array}{c}\text { APRIL-AUGUST } \\
\text { '94 }\end{array}$ & 1.2 .1 & $3,4,5$ \\
\hline $\begin{array}{c}\text { 200 Area Security } \\
\text { Fence Lines }\end{array}$ & $\begin{array}{c}\text { APRIL-AUGUST } \\
\text { '94 }\end{array}$ & 1.2 .1 & 3,4 \\
\hline
\end{tabular}

ACTIVE BURIAL GROUNDS - RESWUAL

\begin{tabular}{|c|c|c|c|}
\hline \hline LOCATION & $\begin{array}{c}\text { APPLICATION } \\
\text { DATE }\end{array}$ & $\begin{array}{c}\text { EFFECTIVENESS } \\
\text { RATING }\end{array}$ & $\begin{array}{c}\text { FISCAL YEAR 1995 } \\
\text { RECOMMENDATION }\end{array}$ \\
\hline \hline $\begin{array}{c}\text { CENTRAL WASTE } \\
\text { COMPLEX }\end{array}$ & NOVEMBER '93 & 1.1 .1 & 3,5 \\
\hline SATELLITE SITES & NOVEMBER '93 & 1.1 .1 & 3,5 \\
\hline
\end{tabular}


ACTIVE BURIAL GROUNDS - SELECTIVE

\begin{tabular}{|c|c|c|c||}
\hline \hline LOCATION & $\begin{array}{c}\text { APPLICATION } \\
\text { DATE }\end{array}$ & $\begin{array}{c}\text { EFFECTIVENESS } \\
\text { RATING. }\end{array}$ & $\begin{array}{c}\text { FISCAL YEAR 1995 } \\
\text { RECOMMENDATION }\end{array}$ \\
\hline \hline $\begin{array}{c}\text { BURIAL } \\
\text { GROUNDS } \\
\text { (GROUND APPLI.) }\end{array}$ & $\begin{array}{c}\text { APRI-AUGUST } \\
\text { '94 }\end{array}$ & 1.2 .1 & 3,5 \\
\hline $\begin{array}{c}\text { BURIAL } \\
\text { GROUNDS } \\
\text { (AERIAL) }\end{array}$ & $\begin{array}{c}\text { APRIL-AUGUST } \\
\text { '94 }\end{array}$ & 4.3 .4 & $3,4,5,6$ \\
\hline
\end{tabular}

WASTE TANK OPERATIONS - RESIDUAL

\begin{tabular}{||c|c|c|c||}
\hline LOCATION & $\begin{array}{c}\text { APPLICATION } \\
\text { DATE }\end{array}$ & $\begin{array}{c}\text { EFFECTIVENESS } \\
\text { RATING }\end{array}$ & $\begin{array}{c}\text { FISCAL YEAR 1995 } \\
\text { RECOMMENDATION }\end{array}$ \\
\hline \hline A TANK FARMS & OCTOBER '93 & 1.1 .1 & 3,8 \\
\hline B TANK FARMS & OCTOBER '93 & 1.1 .1 & 3,8 \\
\hline C TANK FARMS & OCTOBER '93 & 1.1 .1 & 3,8 \\
\hline S TANK FARMS & OCTOBER '93 & 1.1 .1 & 3,8 \\
\hline T TANK FARMS & OCTOBER '93 & 1.1 .1 & 3,8 \\
\hline U TANK FARMS & OCTOBER '93 & 1.1 .1 & 3,8 \\
\hline $\begin{array}{c}\text { GROUT } \\
\text { TREATMENT }\end{array}$ & OCTOBER '93 & 1.1 .1 & 3 \\
\hline GROUT (DRY) & OCTOBER '93 & 1.1 .1 & 3 \\
\hline $\begin{array}{c}\text { 216-U-14 } \\
\text { (STABILIZED) }\end{array}$ & NOVEMBER '93 & 1.1 .1 & 3 \\
\hline
\end{tabular}


WASTE TANK OPERATIONS - SELECTIVE

\begin{tabular}{||c|c|c|c||}
\hline LOCATION & $\begin{array}{c}\text { APPLICATION } \\
\text { DATE }\end{array}$ & $\begin{array}{c}\text { EFFECTIVENESS } \\
\text { RATING }\end{array}$ & $\begin{array}{c}\text { FISCAL YEAR 1995 } \\
\text { RECOMMENDATION }\end{array}$ \\
\hline $\begin{array}{c}\text { 216-U-14 } \\
\text { (STABILIZED) }\end{array}$ & $\begin{array}{c}\text { SPRING/SUMMER } \\
\text { '94 }\end{array}$ & 1.1 .1 & 3 \\
\hline $\begin{array}{c}200 \text { AREA } \\
\text { ACTIVE CRIBS }\end{array}$ & $\begin{array}{c}\text { SPRING/SUMMER } \\
\text { '94 }\end{array}$ & 1.1 .1 & 3 \\
\hline $\begin{array}{c}\text { 200 AREA OPEN } \\
\text { DITCHES \& } \\
\text { PONDS }\end{array}$ & $\begin{array}{c}\text { SPRING/SUMMER } \\
\text { '94 }\end{array}$ & 1.1 .1 & 3 \\
\hline
\end{tabular}

RADIATION AREA REMEDIAL ACTION - RESIDUAL

\begin{tabular}{|c|c|c|c|}
\hline LOCATION & $\begin{array}{c}\text { APPLICATION } \\
\text { DATE }\end{array}$ & $\begin{array}{c}\text { EFFECTIVENESS } \\
\text { RATING }\end{array}$ & $\begin{array}{c}\text { FISCAL YEAR 1995 } \\
\text { RECOMMENDATION }\end{array}$ \\
\hline \hline $\begin{array}{c}\text { 100 AREAS } \\
\text { SURFACE RCA'S }\end{array}$ & OCTOBER '93 & 1.1 .1 & 3 \\
\hline $\begin{array}{c}\text { 100 AREAS } \\
\text { UNDERGROUND } \\
\text { RCA'S }\end{array}$ & OCTOBER '93 & 1.1 .1 & 3 \\
\hline 200 AREA SITES & OCTOBER '93 & 1.1 .1 & 3 \\
\hline
\end{tabular}


RADIATION AREA REMEDIAL ACTION - SELECTIVE (200 AREAS)

\begin{tabular}{|c|c|c|c||}
\hline LOCATION & $\begin{array}{c}\text { APPLICATION } \\
\text { DATE }\end{array}$ & $\begin{array}{c}\text { EFFECTIVENESS } \\
\text { RATING }\end{array}$ & $\begin{array}{c}\text { FISCAL YEAR 1995 } \\
\text { RECOMMENDATION }\end{array}$ \\
\hline \hline FIRST ROUND & MARCH' '94 & 1.1 .1 & 3,5 \\
\hline SECOND ROUND & MAY'94 & 1.1 .1 & 3 \\
\hline THIRD ROUND & JULY '94 & 1.1 .1 & 3 \\
\hline FOURTH ROUND & SEPTEMBER '94 & 1.1 .1 & 3 \\
\hline
\end{tabular}

AERIAL APPLICATION PROGRAM

\begin{tabular}{||c|c|c|c||}
\hline LOCATION & $\begin{array}{c}\text { APPLICATION } \\
\text { DATE }\end{array}$ & $\begin{array}{c}\text { EFFECTIVENESS } \\
\text { RATING }\end{array}$ & $\begin{array}{c}\text { FISCAL YEAR 1995 } \\
\text { RECOMMENDATION }\end{array}$ \\
\hline \hline FIRST ROUND & NO APPLICATION & & $3,4,5$ \\
\hline SECOND ROUND & $\begin{array}{c}\text { MAY '94 (100\% } \\
\text { ACRES) }\end{array}$ & 4.4 .4 & $3,4,5$ \\
\hline THIRD ROUND & $\begin{array}{c}\text { JULY'94 (20\% } \\
\text { ACRES) }\end{array}$ & 4.4 .4 & \\
\hline FOURTH ROUND & NO APPLICATION & & \\
\hline
\end{tabular}




\section{DISTRIBUTION}

\section{Number of Copies}

\section{ONSITE}

2

U.S. Department of Engery, Richland Operations Office

M. J. Elsen

G4-05

Public Reading Room

$\mathrm{H} 2-53$

Westinghouse Hanford Company

M. R. Adams

H6-30

E. L. Barger

T3-25

J. R. Beam

T1-32

M. L. Beavers

G1-19

D. R. Bryant

P7-70

B. W. Cameron

G5-50

R. G. Ciccone

G4-01

R. E. Corliss

T1-32

R. E. Crawford

S6-51

A. D. Danko

O. J. Dorian

N1-41

R. F. Giddings

H6-20

C. C. Gosney

N3-06

J. U. Greenough

$\mathrm{X} 9-05$

R. D. Gustavson

S2-61

W. H. Hayes

R1-05

W. R. Hayes

L5-54

G. A. Haynes

S3-97

C. E. Heiden

S5-62

T. L. Henry

H6-04

B. A. Holmberg

S7-34

G4-02

A. R. Jaramillo

R1-51

C. W. Johnson

S3-55

B. W. Kirby

T1-32

K. P. Knutson

G3-05

\section{Distr-1}




\section{DISTRIBUTION}

\section{Number of Copies}

\section{ONSITE}

Westinghouse. Hanford Company (continued)

C. L. Looney

H6-06

A. K. McDowell

R1-51

J. M. McGee

L6-01

M. Malady

$\mathrm{T} 1-32$

D. E. May

$\mathrm{T} 1-32$

L. S. Messinger

S3-28

R. A. Meznarich

H6-30

D. J. Mouk

H6-30

C. L. Nelson

P7-57

J. M. Nielsen

T4-04

W. L. Osborne

T7-05

R. Pedraza

T4-06

J. F. Riojas

T1-32

L. W. Roberts

L6-05

J. M. Rodriquez (20)

T1-32

C. A. Rosscup

K4-35

R. C. Roos

$\mathrm{H} 6-30$

W. L. Russel

T5-51

B. J. Sall

T1-32

M. M. Sanchez

S2-15

E. Simmons

N1-88

R. M. Tanner

N1-83

R. F. Thorton

$\mathrm{T} 1-32$

R. A. Trevino

X8-29

L. J. Vance

$\mathrm{T} 1-32$

G. E. Van Sickle

H6-05.

S. S. Webb .

$\mathrm{T} 1-32$

D. L. Wegener

S5-03

M. S. Wright

T3-28

Central Files

L8-04

O.S.T.I. (2)

L8-07 